1.序：本研究ではプラントの迅転にタッチ オペレーションを導入した場合の人的特性を シミュレーター実験を通して探り、タッチパ ネル導入時の設計に対するガイドラインの提 案を目指す。

2.実臤対象・装罡：以下に示すような供給 される水を蒸気に変換するシステム（蒸気発 生器と呼ふ）と蒸気が供給される2つのシス テムを制御対象とした。このシステムは架空 ではあるが、現実のプラントの特性をデフォ ルメした形態であり、結果が現実とかけ㙫れ ないように考虑している。

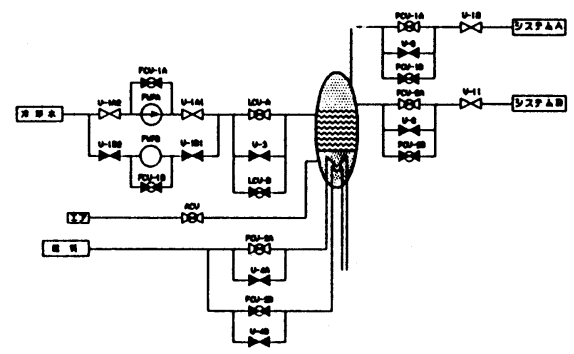

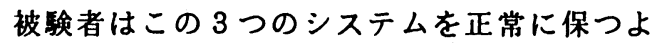
う各機器を制御する。通常バルブの開度等は 自動制御されており、異常事象(マルファクション)が 起きない限り、手動介入する必要はない。そ のため実験に際してはポンプトリップ、バル ブの開・閉固着、制御器つ異常等の異常事象を 予め設定したシナリオに沿って起こさせ、手 動介入の機会を与えるようにした。このマルフ ソクションの内容やその発生時期に関する情報は被 験者には示されす、画面上のパラメータの監
視や䇾報により、異常の同定を行う。実験画 面は上図のようなミミック表示とし（各パラ メータの現在量も表示)、さらに操作したい 機器が表示され ている位置を夕 ッチすれば右図 のような操作部 位が表示される。 実験はシステム の特性および対 応操作に熟練し

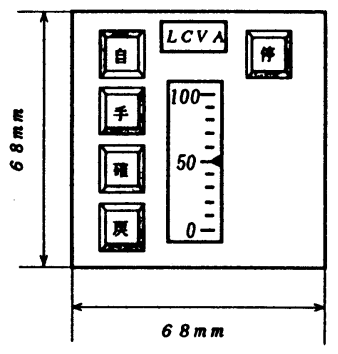
た 4 名の被倹者によって 1 回240秒の実験を与 えられた条件下で各40回行った。

3.キーボードとの比㣀実臨 :

主要パラメーターの制御結果を設定値からの 偏差で評価したところ、下図に示されるよう にタッチオペレーションがキーボードに比較 してはるかに 優れているこ とがわかった。 これはタッチ パネルでは

(1)操作の際に 表示から目 が離れない

(2)機器の䢰択 に関する手

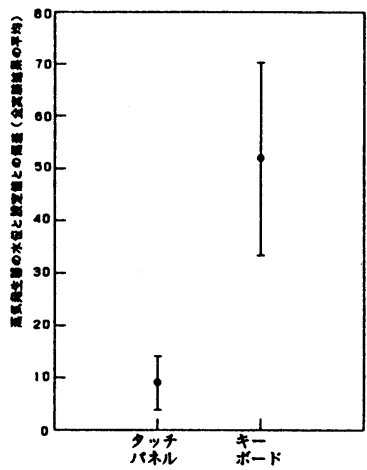
順が容易 という利点があるためであり、次図の対応操 作の所要時間の比較からもその効果を伺うこ 
とができる。

一方、タッチ

パネルでは操

作時の触感に

よるフィード

バックが薄く、

操作感にそし

いという欠点

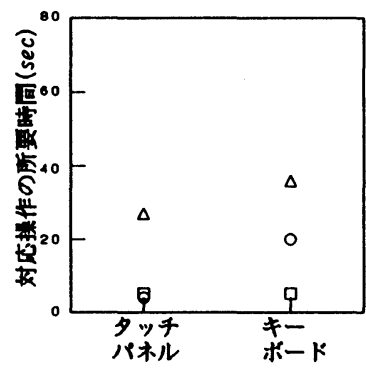

があるが、視覚的（立体的かつ色覚的に考虑

した表示）、㴔覚的（操作時に音をならす）、

配虑、また確認機能の付加といった点を組み

込むことにより、十分補えることがこの客観

的結果だけでなく、主钼的意見でも得られた。

\section{4. 操作部位の表示位国についての実臤}

操作部位を選択

した機器の周辺

に表示した場合

と、選択した機

器に関わらず同

じ位置に表示す

るようにした場

合とを比較した。

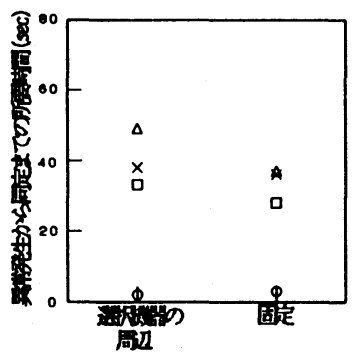

ただし後者の場合、他の情報を鿵ぺいしない よう表示位置を選定した。その結果、表示位 置によろ制御結果の変化はほとんど見られな

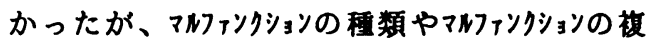
合的な発生の場合には、上図のような異常の 同定に要する時間に違いが生じた。この原因 を考えてみると機器周辺に表示した場合には、

・情報の隐べのために異常の発見が暑れる。

・操作中周囲のバルブ等の状態がつかめない。 といった状況が起こる可能性があり、そのた めに随時ではないが、翼常の同定が遅れるケ 一スもでできたと考えられる。当然、プラン 卜の運転では、運㶿に支障を来さない範囲で あればできる限りエラーの起こる要因を排除 する必要がある。固定位贯に表示した場合、 選択した機器との対応か值接わかりにくい、 という問題はあるが、これは選択した機器が どれかを表示する際に、色等で強調表示させ
れば問題ないことが、確認された。このよう に表示位置そのものより、表示される操作部 位が他の情報を嗳ぺいするか否かが重要であ ることが判る。従って、表示位置を固定する 方式がより好ましいといえる。

5. 操作部位の大きさについての実珠

小: 1 つの操作ボタンの大きさが指の腹程度 中:過去の単純入力実険において確認されて

ろ、正しく入力できる最小の大きさ。 大:中よりも大きいもの。

(小: $10 * 10$ 中 $15 * 15$ 大 $20 * 20$ 単位 $\mathrm{mm}$ ) 部位が小さいと、 位置決めが嚾し いので、操作回 数を少なく、湅 かな調整操作を 避ける傾向があ ろ。しかし、そ れは実験結果か らもわかるよう

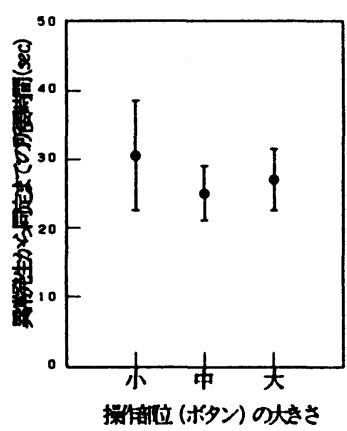
に、単純入力実験で推奖された最小の大きさ より小さい場合(「中」))にのみ観察され、ここ でいう「中」以上の大きさでは問題はない。逆 に、大きくなりすきると、操作自体が雑にな ろ傾向も被験者によっては見られた。つまり、 単純入力実鍳で得られた操作部位の大きさが、 本実験のようなプラント制御でも望ましい大 きさであることが確認された。

6.桔詥：このように一般的な操作であれば、 従来の操作機器よりタッチパネルは総合的な 意味で好ましいことが確認され、またプラン トの運転に導入する祭に配虑すへきいくつか の以下に示すような基本的指針を得た。

・操作感の薄さを補うために、視覚的・聴覚的 な配虑および確認機能が有効である。

・操作部位の表示はできる限りそのほかの情 報を鿵ぺいしないよう設計すへきである。

・操作部位の各ボタンの大きさは、単純入力 実験で確苑された正しく入力できる最小の 大きさ(約 $\left.225 \mathrm{~mm}^{2}\right)$ が望ましい。 